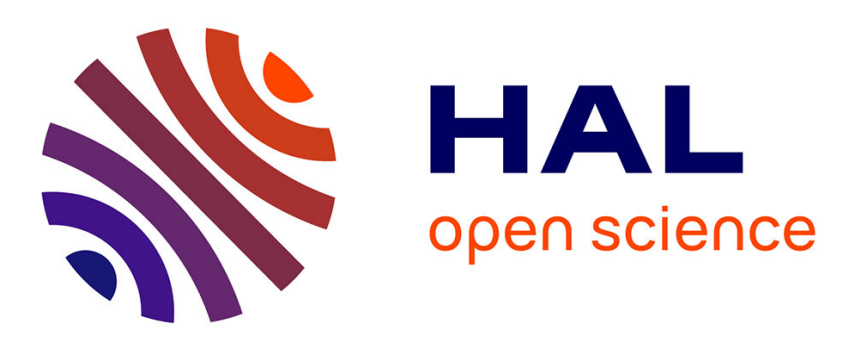

\title{
High order DGTD solver for the numerical modeling of nanoscale light/matter interaction
}

\author{
Stéphane Lanteri, Claire Scheid, Jonathan Viquerat
}

\section{To cite this version:}

Stéphane Lanteri, Claire Scheid, Jonathan Viquerat. High order DGTD solver for the numerical modeling of nanoscale light/matter interaction. Icosahom 2016 - International Conference on Spectral and High Order Methods, Jun 2016, Rio de Janeiro, Brazil. hal-01404672

HAL Id: hal-01404672

https://hal.inria.fr/hal-01404672

Submitted on 29 Nov 2016

HAL is a multi-disciplinary open access archive for the deposit and dissemination of scientific research documents, whether they are published or not. The documents may come from teaching and research institutions in France or abroad, or from public or private research centers.
L'archive ouverte pluridisciplinaire HAL, est destinée au dépôt et à la diffusion de documents scientifiques de niveau recherche, publiés ou non, émanant des établissements d'enseignement et de recherche français ou étrangers, des laboratoires publics ou privés. 


\title{
HIGH ORDER DGTD SOLVER FOR THE NUMERICAL MODELING OF NANOSCALE LIGHT/MATTER INTERACTION
}

\author{
STÉPHANE LANTERI* , CLAIRE SCHEID ${ }^{\dagger}$ AND JONATHAN VIQUERAT* \\ * Inria Sophia Antipolis-Méditerranée Research Center, France. \\ email: \{Stephane.Lanteri,Jonathan.Viquerat\}@inria.fr \\ $\dagger$ University of Nice-Sophia Antipolis, France. \\ email: Claire.Scheid@unice.fr
}

\begin{abstract}
Nanophotonics is the field of science and technology which aimed at establishing and using the peculiar properties of light and light-matter interaction in various nanostructures. Nanophotonics includes all the phenomena that are used in optical sciences for the development of optical devices. Because of its numerous scientific and technological applications (e.g. in relation to telecommunication, energy production and biomedicine), nanophotonics represents an active field of research increasingly relying on numerical modeling beside experimental studies. Plasmonics is a related field to nanophotonics involving metalic nanostructures whose optical scattering is dominated by the response of the conduction electrons [1]. The numerical modeling of light interaction with metallic nanostructures requires to solve the system of time-domain Maxwell equations coupled to appropriate models of physical dispersion in the metal such as the Drude and Drude-Lorentz models. In this talk, we will report on our recent efforts aiming at the development of a family of high order finite element type time-domain solvers for the numerical treatment of nanophotonics applications in the linear regime. The proposed method is an extension of the so-called DGTD (Discontinuous Galerkin Time-Domain) method that was initially proposed for the simulation of electromagnetic wave propagation in non-dispersive heterogeneous media at microwave frequencies [2]-[3]. For the numerical treatment of dispersion models in metals, we have adopted an Auxiliary Differential Equation (ADE) technique leading to solve the time-domain Maxwell equations coupled to a ODEs.
\end{abstract}

\section{REFERENCES}

[1] S.A. Maier, "Plasmonics- Fundamentals and applications", Springer (2007).

[2] J.S. Hesthaven and T. Warburton, "Nodal High-Order Methods on Unstructured Grids. I. Time-Domain Solution of Maxwell's Equations", J. Comput. Phys., 181:1, 186-221, (2002).

[3] L. Fezoui and S. Lanteri and S. Lohrengel and S. Piperno, "Convergence and Stability of a Discontinuous Galerkin Time-Domain Method for the 3D Heterogeneous Maxwell Equations on Unstructured Meshes", ESAIM: Math. Model. Numer. Anal., 39:6, 1149-1176, (2005). 